\title{
Erratum to: Effects of the intradiscal implantation of stromal vascular fraction plus platelet rich plasma in patients with degenerative disc disease
}

\author{
Kristin Comella ${ }^{1^{*}} \mathbb{B}$, Robert Silbert ${ }^{2}$ and Michelle Parlo ${ }^{1}$
}

\section{Erratum to: J Transl Med (2017) 15:12 DOI 10.1186/s12967-016-1109-0}

In the original version of this article [1], published on 13 January 2017, the author names have been displayed in the wrong order. In this Erratum the incorrect names and correct names are shown. The original publication of this article has been corrected.

Originally the author names have been published as:

- Comella Kristin

- Silbert Robert

- Parlo Michelle

The correct names are:

- Kristin Comella

- Robert Silbert

- Michelle Parlo

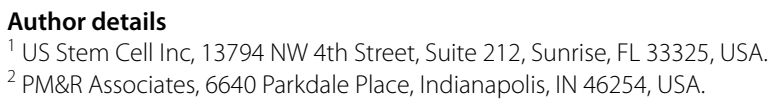

The online version of the original article can be found under doi:10.1186/s12967-016-1109-0.

\section{Publisher's Note}

Springer Nature remains neutral with regard to jurisdictional claims in published maps and institutional affiliations.

Published online: 22 May 2017

\section{Reference}

1. Comella K, Silbert R, Parlo M. Effects of the intradiscal implantation of stromal vascular fraction plus platelet rich plasma in patients with degenerative disc disease. J Transl Med. 2017;15:12. doi:10.1186/ s12967-016-1109-0.

*Correspondence: kcomella@us-stemcell.com

1 US Stem Cell Inc, 13794 NW 4th Street, Suite 212, Sunrise, FL 33325, USA

Full list of author information is available at the end of the article 